\title{
KEMANDIRIAN ANAK DITINJAU DARI JENIS HOMESCHOOLING
}

\author{
Yunita Risnandini ${ }^{1}$, Sriningsih $^{2}$ \\ ${ }^{12}$ Universitas Mercu Buana Yogyakarta \\ ${ }^{2}$ sriningsih@gmail.com
}

\begin{abstract}
Abstrak
Penelitian ini bertujuan untuk mengetahui kemandirian anak ditinjau dari jenis homeschooling. Hipotesis yang diajukan dalam penelitian ini adalah ada perbedaan kemandirian anak ditinjau dari jenis homeschooling. Kemandirian anak dengan homeschooling tunggal lebih tinggi dari pada anak dengan homeschooling komunitas. Subjek penelitian adalah anak duduk di kelas 4, 5, dan 6 SD, sebanyak 26 orang yang terdiri dari 14 orang anak homeschooling komunitas dan 12 orang anak homeschooling tunggal , yang berada di lembaga belajar homeschooling primagam dan homeschooling Kak Seto. Alat pengumpul data menggunakan skala yaitu skala Kemandirian Anak. Teknik analisis data yang digunakan adalah statistik kompratif dengan menggunakan independent sampel t-tes. Berdasarkan hasil analisis data, diperoleh koefisien perbedaan kemandirian antara anak dengan homeschooling tunggal dan anak dengan homeschooling komunitas sebesar 2,505; p < 0,05 dengan rerata kemandirian anak homeschooling tunggal sebesar 105,58 dan rerata anak homeschooling komunitas sebesar 94, artinya kemandirian pada anak homeshooling tunggal lebih tinggi di pandingkan anak yang homeschooling komunitas.
\end{abstract}

Kata kunci : kemandirian anak, jenis homeschooling

\section{CHILDREN'S INDEPENDENCY REVIEWED FROM HOMESCHOOLING TYPES}

\author{
Yunita Risnandini ${ }^{1}$, Sri Muliati Abdullah ${ }^{2}$ \\ ${ }^{12}$ Universitas Mercu Buana Yogyakarta \\ ${ }^{2}$ muliatiyogya@gmail.com
}

\begin{abstract}
This study aims to determine the independence of children in terms of the type of homeschooling. The hypothesis proposed in this study is that there are differences in children's independence in terms of the type of homeschooling. The independence of a single homeschooling child is higher than a community homeschooling child. The subjects of the study were 26 elementary school students in grades 4, 5 and 6, consisting of 14 community homeschooling children and 12 single homeschooling children, who were students in Kak Seto's Homeschooling and Primagama Homeschooling. The data collection tool used the Children's Independence scale. The data analysis technique used was comparative statistics using independent sample t-tests. Based on the results of data analysis, obtained the coefficient of independence difference between single homeschooling children and community homeschooling children were 2.505; $p<0.05$ with the average independence of single homeschooling children at 105.58 and the mean of community homeschooling children at 94 . This means that the independence in single homeschooling children is higher compared to community homeschooling children.
\end{abstract}

Keywords: children's independency, type of homeschooling

\section{PENDAHULUAN}

Anak bukanlah orang dewasa dalam bentuk kecil, tetapi adalah seorang individu dengan ciri khusus yang dalam perkembangan pribadi dan sosialnya memerlukan bimbingan dan tuntunan. Anak memerlukan tempat dimana ia merasa aman, diberikan kasih sayang, serta diterima dan diakui. Oleh karena itu orangtua hendaknya peduli akan kebutuhankebutuhan anak yang harus dipenuhi, terutama 
berkenaan dengan pendidikan anak. Keluarga dalam hubungannya dengan anak, identik sebagai tempat atau lembaga pengasuhan yang paling dapat memberikan kasih sayang, pendidikan, serta pengalaman hidup yang positif dan berharga.

Ketika anak memasuki usia sekolah dasar, anak mulai dihadapkan pada lingkungan sosialnya. Dengan memasuki dunia sekolah dan masyarakat, anak dihadapkan pada tuntutan sosial yang baru. Mereka mulai belajar berinteraksi dengan orang lain, menemukan identitas diri dan peran jenis kelaminnya, melatih kemandirian dan mampu berinisiatif serta mengatasi kecemasan dan konflik secara tepat dan mengembangkan moral dan kata hati yang benar dan serasi (Kedaulatan Rakyat, 2011).

Havigurst (Susana, 2000), seorang ahli Psikologi mengatakan bahwa setiap anak pada setiap tahap usia perkembangan akan menghadapi tugas-tugas perkembangan, tiap tugas perkembangan harus dikuasai anak, karena mengarahkannya pada kemandirian dan kemampuan untuk bertanggung jawab secara moral dan sosial. Kemandirian dapat diartikan sebagai suatu keadaan individu yang tidak merasa tergantung kepada siapa saja, mengerti dan mengenali dirinya sendiri, serta bertanggung jawab (Mu'tadin, 2002). Anak yang mandiri adalah anak yang dapat melakukan segala aktifitas sehari harinya dengan usaha sendiri, ada rasa ingin tahu untuk mencoba sesuatu yang baru dengan usaha sendiri, memiliki kepercayaan diri dalam mengerjakan tugas-tugas dan dapat mengatasi masalahnya sendiri sesuai dengan tingkah dan taraf usianya (Barnadib \& Kartono, 2002).

Anak yang berusia 9;0-12;0 tahun atau berada di kelas 4,5,6 sekolah dasar sikap mandiri telah terlihat jelas. Hal ini ditandai dengan rasa ingin tahu yang besar, ingin belajar dan dapat membuat peraturan dengan caranya sendiri (Partini, 1987). Kemandirian merupakan modal dasar bagi anak dalam menentukan sikap dan perbuatan terhadap lingkunganya. Rini (2005) menanmbahkan arti penting kemandiian diantaranya adalah (a) mendapatkan keterampilan mengelolah hidup; (b) belajar mengantisipasi; (c) menumbuhkan pikiran kritis; (d) lebih bertanggung jawab; dan (e) melatih daya tahan mental.

Sarwono (2000) mengatakan bahwa anak sebenarnya merupakan pribadi yang berdiri sendiri dan terpisah dari orangtua. Anak akan mengalami perubahan, semakin bertambah usia, berkembang kemampuan fisik dan psikisnya, mulai ingin memisahkan diri, serta sikap bergantung semakin berkurang seharusnya orangtua jeli dan benar- benar memperhatikan pendidikan yang sebaiknya diberikan kepada anak, yaitu pendidikan yang menjadikan anak merasa nyaman, tenang dan tidak merasa terbebani.

Pada masa sekarang ini banyak sekali bermunculan lembaga pendidikan anak, mulai dari pendidikan formal sampai dengan pendidikan non formal yang memiliki tujuan untuk mengatasi keterbatasan-keterbatasan dalam menyediakan bimbingan dan layanan belajar secara individual kepada anak-anak selaku peserta didik. Selain itu, pembelajaran secara klasikal sering menyebabkan peserta 
didik mempunyai hambatan belajar yaitu kurangnya perhatian intensif dari guru. Berlakunya seperangkat aturan yang sangat mengikat bagi peserta didik, penerapan disiplin yang terlalu kaku, dan suasana belajar yang terlalu formal tanpa disadari sering membebani dan memasung kreativitas peserta didik. Sebagai contoh kasus, ketika ada siswa yang tidak mematuhi guru atau peraturan sekolah, maka siswa akan mendapatkan sanksi, padahal hal tersebut terjadi karena guru atau pihak sekolah tidak mengetahui minat dan kemauan anak, sehingga anak yang bermasalah sering diklaim sebagai anak yang mengalami gangguan ADHD (Attention DefisitHyperactivity Disoder) atau sebaliknya anak yang berkarakter pendiam, pemalu, bosan berada di dalam ruangan kelas dan cenderung menerawangkan pikirannya pada hal- hal yang menarik minatnya diberi label "autistik" dan mereka harus segera diperiksakan ke dokter. Hal inilah yang terkadang membuat para orangtua marah dan jenuh dengan pihak sekolah yang begitu mudah melabeli anak mereka (Kho, 2007).

Menyikapi situasi di atas mulailah bermunculan lembaga- lembaga pendidikan alternatife sebagai upaya mengatasi persoalan di atas, salah satunya adalah homeschooling. Homeschooling adalah sebuah keluarga yang memilih untuk bertanggung jawab sendiri atas pendidikan anak-anak dan mendidik anaknya dengan berbasisrumah. Pada homeschooling, orangtua bertanggung jawab sepenuhnya atas proses pendidikan anak; sementara pada sekolah reguler tanggung jawab itu didelegasikan kepada guru dan sistem sekolah
(Sumardiono, 2007).

$$
\text { Metode belajar homeschooling, }
$$
setidaknya ada tiga manfaat yang didapatkan, diantaranya pertama, homeschooling mengingatkan atau menyadarkan para orangtua bahwa pendidikan untuk anak-anak tidak dapat dipasrahkan sepenuhnya kepada sekolah formal; kedua homeschooling dapat menampung anak-anak yang karena alasanalasan tertentu tidak dapat belajar di sekolah formal; dan ketiga, homeschooling dapat menjadi sparring partner sekolah formal dan non formal dalam upaya mereka untuk meningkatkan kualitas pendidikannya (Mulyadi, 2007).Pendidikan model homeschooling membantu mengembangkan potensi anak secara optimal baik dalam pengetahuan, keterampilan, sikap, dan kepribadian dengan menekankan pada penguasaan pengetahuan, keterampilan fungsional, dan pengembangan sikap, serta kepribadian profesional sekaligus memerluas akses terhadap pendidikan dasar dan menengah (Sumardiono,2007).

Dalam pendidikan homeschooling, anak yang akan menentukan mata pelajaran apa yang nantinya dipelajari. Dengan demikian, anak secara tidak langsung diajarkan dan dilatih untuk mandiri dan bertanggung jawab.

\section{Homeschooling diterapkan dalam}

beberapa bentuk yaitu homeschooling tunggal, dimana anak belajar mandiri dirumah, serta didampingi oleh orangtua secara pribadi atau pihak-pihak tertentu dan komunitas homeschooling, dimana beberapa siswa homeschooling bergabung dalam satu komunitas untuk belajar di suatu lembaga 
homeschholing (Suryadi, 2006). Penerapan homeschooling ini tergantung dari kebutuhan setiap homeschooler dan disesuaikan dengan kemampuan orangtua dan minat anak (Kembara, 2007).

Berdasarkan permasalahan di atas, peneliti tertarik untuk mengadakan penelitian yang lebih difokuskan pada pembentukan kemandirian anak. Oleh karna itu dirumuskan permasalahan bagaiman kemandirian anak ditinjau dari jenis homeschooling ?

Penelitian ini bertujuan ingin mengetahui kamandirian anak ditinjau dari jenis homeschooling.

\section{KAJIAN PUSTAKA}

Kemandirian berasal dari kata mandiri yang berarti dalam keadaan dapat berdiri sendiri, tidak tergantung pada orang lain (Depdikbud,1990). Kemandirian, menurut Benardib (M'utadin, 2002) merupakan perilaku mampu berinisiati, mampu mengatasi hambatan atau masalah, mempunyai rasa percaya diri dan dapat melakukan sesuatu sendiri tanpa bantuan orang lain. Pendapat tersebut diperkuat oleh Kartini \& Kartono (1987) yang mengatakan bahwa kemandirian adalah hasrat untuk melakukan segala sesuatu bagi diri sendiri. Aspek-aspek kemandirian adalah kebebasan, progresif dan ulet, pengendalian diri di dalam (intenal locus of control), inisiatif, dan kemantapan diri (Masrun, dkk, 1986).

Aspek kebebasan yaitu tindakan yang dilakukan atas kehendak sendiri bukan karena paksaan orang lain dan tidak tergantung kepada orang lain. Aspek progresif dan ulet ditunjukkan dengan adanya usaha untuk mengejar prestasi, penuh ketekunan, merencanakan, dan mewujudkan harapannya. Aspek pengendalian diri dari dalam (internal locus of control) adanya perasaan mampu unuk menghadapi masalah yang dihadapi, kemampuan mengendalikan tindakan-tindakan serta mem pengaruhi lingkungan atas usahanya sendiri. Aspek inisiatif adanya kemampuan unuk berfikir dan bertindak secara original (asli), kreatif dan penuh inisiatif. Aspek kemantapan diri yang terakhir adalah rasa percayau menerima keadaan diri dan memperoleh kepuasaan dari usahanya.

Pembentukan kemandirian pada anak, pada prinsipnya adalah dengan memberikan kesempatan terlibat dalam berbagai aktivitas (Astuti, 2004). Anak-anak bisa mandiri jika orangtua memberikan dorongan pada perkembangan kemandiriran mereka dengan melatih mereka mengambil keputusan berkenaan dengan diri mereka dan menunjukan kepada mereka bahwa mereka dapat dipercaya.

Berdasarkan pendapat Astuti dan Parker di atas maka dapat disimpulkan bahwa pembentukan kemandirian pada anak tidak bisa lepas dari peran orangtua dalam mendidik dan mengasuh anak terutama dalam hal pemberian dorongan terhadap motivasi, tanggung jawab dan latihan yang berhubungan dengan pengambilan keputusan dalam mengatur kehidupan mereka sendiri, serta memberikan kepercayaan untuk mengurus dirinya sendiri.

Drost (2002) menyatakan bahwa kemandirian anak dipengaruhi oleh beberapa faktor yaitu keluarga yang merupakan sebuah 
lembaga pertama dalam menentukan kemandirian anak, faktor yang ke dua yaitu sekolah merupakan institusi kedua dalam pendidikan dan pengajaran, bertujuan membentuk anak menjadi individu sehat, baik fisik maupn psikis, faktor yang ke tiga ialah usia Kemandirian berkembang setahap demi setahap demi setahap sesuai dengan perkembangan kematangan seseorang dan baru tercapai penuh saat anak mencapai remaja akhir. Menurut Harlock (1990), kemampuan motorik anak harus berkembang terlebih dahulu agar mereka bisa mandiri dalam mengerjakan tugas-tugas rutin seperti mandi, makan, atau memakai baju tanpa bantuan orang lain. Dan faktor yang terakhir ialah urutan kelahiran dan jumlah anak dalam keluarga, Masrun, dkk (1986) mengemukan bahwa posisi seseorang anak dalam keluarga bisa dipakai untuk menjelaskan perbedaanperbedaan kepribadian di antara anak-anak yang urutan kelahirannya berbeda- berbeda. Dalam penilitian tersebut dijelaskan bahwa individu yang mandiri berasal dari keluarga besar (lebih dari tiga orang). Homeshooling merupakan sebuah program belajar mandiri di rumah dengan pendekatan yang bersifat individual (Soekresno, 2004). Setiap anak yang mengikuti homeschooling memeroleh pendidikan yang sesuai dengan potensi dan kecenderungan minat masing-masing, setiap karakter khas anak dan perkembangan dirinya dapat selalu dipantau orangtua secara personal. Di sini orangtua bertanggung jawab secara aktif atas proses pendidikan anaknya (Sumardiono, 2007). Suryadi (2006) menglasifikasikan homeschooling sesuai dengan tujuan, kondisi dan kebutuhan masing-masing orangtua atau keluarga.

Jenis-jenis homeschooling adalah: (1). homeschooling tunggal; (2). homeschooling komunitas.

Homeschooling tunggal adalah format sekolah rumah yang dilaksanakan oleh orangtua dalam satu keluarga tanpa bergabung dengan homeschooler lainnya.

Homeschooling komunitas merupakan gabungan beberapa homeschooler dimana yang menyusun dan menentukan silabus, serta bahan ajar bagi anak-anak homeschooler adalah lembaga, termasuk menentukan beberapa aktivitas dasar (olahraga, musik atau seni dan bahasa) serta fasilitas tempat proses pembelajaran dilaksanakan pada waktuwaktu tertentu.

Homeschooling tunggal, merupakan homeschooling yang hanya melibatkan orang tua dalam satu keluarga dan tidak bergabung dengan keluarga lainnya. Pada homeschooling tunggal peran orangtua sangatlah penting sebagai pembimbing, teman belajar ataupun penilai. Homeschooling ini memiliki tingkat fleksibilitas yang tinggi karena dapat dilakukan dimana saja dan kapan saja ( Lucky Fish, 2010). Sementara itu, jenis homeschooling komunitas merupakan gabungan beberapa homeschooling, yang menyusun dan menentukan silabus, RPP (Rancangan Program Pembelajaran), bahan ajar, sarana, serta jadwal pembelajaran adalah lembaga bukan peserta didik. Mereka hanya bisa memilih apa yang sudah di siapkan oleh lembaga, tetapi mereka memilik kebebas dalam berpakaian dan dapat belajar santai. Peserta 
didik yang mengikuti homeschooling komunitas memiliki ruang gerak sosialisasi yang lebih luas dibandingkan dengan jenis homeschooling tunggal.

Dalam homeschooling tunggal, anak cenderung lebih banyak memiliki kebebasan dibandingan homeschooling komunitas, karena dalam homeschooling tunggal anak dituntun untuk mengerjakan sesuatu sendiri, dan menemukan sesuatu sendiri dengan bantuan pendidik. Anak mencari tahu segala sesuatu yang ingin diketahuinya. Anak memilih apa yang disukainya dan apa yang tidak disukainya dan anak menentukan proses belajarnya sendiri, misalnya anak bebas dalam memlilih jadwal pelajaran yang ingin dipelajari serta waktu yang fleksibel, sehinga anak memiliki kemandirian dalam belajarnya (Ali dalam Sumardiono, 2007).

$$
\text { Anak yang belajar dengan }
$$
homeschooling di dalam rumah juga tetap dituntut untuk berprestasi pada belajar. Namun pencapaian prestasi pada anak dengan pembelajaran berbasis homeschooling tunggal cenderung kurang baik, hal tersebut dikarenakan tidak adanya kompetisi dan persaingan yang memotivasi anak untuk meraih prestasi, menyebabkan anak tidak bisa membandingkan sampai dimana kemampuannya dibanding anak-anak lain seusia (elly,2006). Dalam homeschooling tunggal anak cendeung lebih mampu menghadapi permasalahnya sendiri, hal tersebut menandakan adanya inisiatif pada anak (Santrock dalam Sarwono 2002). Oleh karena itu anak akan merasa percaya diri terhadap kemampuannya serta mampu menerima keadaan diri melalui usahanya.

Kemantapan diri yang dimiliki anak dengan homeschooling tunggal dan komunitas homeschooling tidak jauh berbeda, dikarenakan anak dalam homeschooling memokuskan pada kehidupan dan kemampuan yang dimiliki anak, yang akan membentuk anak bisa menerima dirinya dan percaya diri atas kemampuan, tidak terpaku pada nilai atau angka yang menyebabkan anak tidak percaya diri dan akhirnya mendorong timbulnya perilaku menyontek untuk mendapatkan nilai bagus (Sumardiono, 2008).

Bentuk kemandirian yang dihasilkan dari penerapan kedua jenis homeschooling tersebut sangat bervariatif atau heterogen. Salah satunya adalah anak memiliki pengendalian diri yang bagus serta memiliki kepribadian yang tangguh, akhlak yang mulia, dan anak akan membentuk sikap terampil serta anak mampu memahami secara mendalam tentang pelajaran tersebut dan pengetahuan tersebut dapat melekat dalam pribadinya.

Berdasarkan tinjauan teoritis yang telah diuraikan di atas, maka hipotesis yang diajukan adalah ada perbedaan kemandirian anak ditinjau dari jenis homeschooling.

\section{METODE}

Variabel tergantung dalam penelitian ini ialah kemandirian anak. Kemandirian anak merupakan suatu kondisi atau keadaan yang memungkinkan anak untuk mampu menyelesaikan tugas yang diberikan oleh orang lain, tutor atau pun orangtua dengan tidak mengharapkan atau menggantungkan kepada orang lain, serta dapat melakukan 
kegiatanya sendiri tanpa bantuan orang lain. Kemandirian anak diukur dengan menggunakan Skala Kemandirian yang disusun berdasarkan pendapat Masrun, dkk (1986) meliputi inisiatif, bebas, progresif dan ulet, pengendalian diri dan kemantapan diri. Semakin tinggi skor yang diperoleh,berarti semakin tinggi kemandirian anak, dan sebaliknya, semakin rendah skor berarti semakin rendah kemandirian anak.

Sedangkan Variabel bebas dalam penelitian ini adalah variasi jenis lembaga pendidikan nonformal yang melaksanakan proses layanan pendidikan secara sadar, teratur dan terarah, dilakukan oleh orangtua atau keluarga, menggunakan kurikulum Pendidikan Nasional sebagai acuannya.

Jenis homeschooling di bedakan atas 2 jenis yaitu , Homeschooling Tunggal, adalah format sekolah rumah yang dilaksanakan oleh orangtua dalam satu keluarga yang dengan sengaja tidak bergabung dengan keluarga lain yang juga menerapkan sekolah rumah tunggal, sedangkan homeschooling komunitas, merupakan beberapa homeschooling yang bergabung di lembaga pendidikan nonformal, sedangkan penyusun dan penentuan silabus, serta bahan ajar bagi anakanak homeschooling adalah lembaga tersebut, termasuk menentukan beberapa aktivitas dasar (olahraga, musik atau seni dan bahasa). Fasilitas dan tempat proses belajar mengajar diselenggarakan oleh lembaga dengan waktu yang sudah ditentukan oleh lembaga.

Subjek penelitian ini adalah peserta homeschooling di Primagama dan homeschooling Kak Seto dengan jenis homeschooling tunggal dan komunitas, masing-masing sebanyak 14 orang anak homescholing Komunitas dan 12 anak homeschooling tunggal. Subjek dalam penelitian ini adalah berjenis kelamin laki-laki dan perempuan, dan duduk di kelas 4,5, 6, karena sikap mandiri telah terlihat jelas pada usia anak 4, 5, dan 6 (Partini, 1987).

Metode pengumpul data yang digunakan dalam penelitian ini adalah Metode Skala. Peneliti menggunakan skala sebagai metode pengumpulan data, karena variabel kemandirian merupakan bagian dari aspek kepribadian yang tidak dapat diungkap secara langsung.

Jenis skala yang digunakan adalah model metode summated rating dari Likert yang telah di modifikasi dengan menggunakan 4 alternatif jawaban yaitu Sangat Sesuai (SS), Sesuai (S), Tidak Sesuai (TS), dan Sangat Tidak Sesuai (STS). Penilaian untuk jawaban favorabel berturut-turut adalah 4 untuk jawaban Sangat Sesuai (SS), 3 Sesuai (S), 2 Tidak Sesuai (TS), dan 1 Sangat Tidak Sesuai (STS). Pernyataan anfavorabel menggunakan urutan kebalikan dari pernyataan favorabel yaitu nilai 4 untuk jawaban Sangat Tidak Sesuai (STS), nilai 3 untuk jawaban Tidak Sesuai (TS), nilai 2 untuk jawaban Sesuai (S), dan nilai 1 untuk jawaban Sangat Sesuai (SS).

Pada penelitian ini penulis menggunakan batasan 0,30 sebagai batasan nilai koefisien korelasi. Suatu aitem memiliki validitas tinggi apabila memiliki nilai koefisien korelasi atem total (rix) lebih atau sama dengan 0,30 atau apabila tidak terpenuhi dapat menurunkan batasan 0,25 dan minimal 0,20 (Azwar, 2003). 
Berdasarkan hasil sebaran Skala Kemandirian Anak yang berjumlah 40 aitem, dapat diketahui adanya tujuh (7) aitem yang dinyatakan gugur, sehingga hanya 33 aitem yang dianggap valid dengan koefisien validitas aitem yang berkisar antara 0,300 sampai 0,62 dan koefisien reliabiltas alpha 0,095 .

Pada penelitian ini data dianalisis secara statistik komparatif dengan menggunakan independent sampel t-tes, yang bertujuan mencari perbedaan.

\section{HASIL DAN PEMBAHASAN}

Hasil uji normalitas sebaran data kemandirian menunjukkan skor K-S-Z sebesar 0,099, $\mathrm{p}=0,200$ ( $\mathrm{p}>0,05)$. Jadi dapat dinyatakan bahwa sebaran data variabel yang digunakan mengikuti distribusi normal.

Hasil uji homogenitas data kemandirian anak menunjukkan koefisien homogenitas sebesar 3,113 dengan $p=0,090>0,05$. Hal ini menunjukkan variasi data kemandirian anak bersifat homogen.

Penelitian ini menggunakan uji independent sample t-test untuk menguji hipotesis. Uji hipotesis dilakukan untuk mengetahui perbedaan kemandirian anak homeschooling tunggal dengan anak homeschooling komunitas. Hasil analisis data menunjukkan bahwa terdapat perbedaan kemandirian antara anak dengan homeschooling tunggal dan anak dengan homeschooling komunitas $(t=2,505 ; \mathrm{p}=0,019$ $(\mathrm{p}<0,05)$. Rerata kemandirian anak homeschooling tunggal sebesar 105,58 dan rerata anak homeschooling komunitas 94.

\section{Pembahasan}

Hasil penelitian menunjukkan bahwa terdapat perbedaan antara kemandirian antara anak dengan homescooling tunggal yang mempunyai kemandirian lebih tinggi dari pada anak dengan homescooling komunitas. Hal ini sesuai dengan pendapat Drost (2002) yang menyatakan bahwa salah satu faktor yang membentuk kemnadirian anak yaitu pengaruh sekolah. Salah satu bentuk sekolah yang saat ini banyak dipilih oleh orangtua yaitu homeschooling dengan beragam jenis. Salah satunya homeschooling dengan jenis tunggal. Homeschooling tunggal adalah format sekolah rumah yang dilaksanakan oleh orangtua dalam satu keluarga tanpa bergabung dengan homeschooler lainnya.

Edwards (2006) menegaskan bahwa karakteristik individu memengaruhi cara orang dewasa mengasuh anak-anak mereka, khususnya yang berhubungan dengan kedisiplinan, kemandirian dan berusaha keras mengajarkan kepada anak-anak apa yang mereka perlu di ketahui dan dikerjakan agar menjadi orang yang bahagia, percaya diri, dan bertanggung jawab di masyarakat. Dalam pendidikan homeschooling, anak sebagai penentu mata pelajaran apa yang nantinya dipelajari. Dengan demikian, anak akan lebih bertanggung jawab dan mandiri. Hal ini senada dengan pendapat Sarwono (2000) yang mengatakan bahwa anak sebenarnya merupakan pribadi yang berdiri sendiri dan terpisah dari orangtua.

Berdasarkan hasil penelitian yang dilaksanakan ditemukan bahwa sebagian besar responden dengan homescholling tunggal 
memiliki kemandirian yang tinggi $(83,33 \%$.) Proses belajar dalam penerapan jenis homeschooling tunggal sangar menunjang pembentukan kemandirian anak. Hal ini didasarkan karena anak dengan homeschooling tunggal memiliki kesempatan untuk menentukan dan terlibat dalam setiap aktivitas.

Apabila dilihat dari aspek kemandirian berupa kebebasan, anak dengan homeschooling tunggal lebih bebas dalam menentukan konsep pembelajaran atau apa yang akan mereka kerjakan dan yang akan dicapai dibandingkan dengan homeschooling komunitas. Pada anak dengan homeschooling tunggal, anak cenderung lebih banyak memiliki kebebasan dibandingan homeschooling komunitas, karena dalam homeschooling tunggal anak dituntun untuk mengerjakan sesuatu sendiri, dan menemukan sesuatu sendiri dengan bantuan pendidik.

Proses pemecahan masalah merupakan salah satu komponen yang terdapat dalam lingkup inisiatif, sehingga, anak dengan homeschooling tunggal memliki kemampuan inisiatif yang lebih tinggi jika dibandingkan anak dengan homeschooling komunitas. Hal ini diperkuat oleh penelitian Sumardiono (2007), bahwa anak yang berhomeschooling tunggal akan semakin mandiri karena terbiasa aktif dan inisiatif dalam proses pendidikannya serta percaya diri terhadap kemampuannya.

Dari aspek progresif dan ulet menunjukkan bahwa anak dengan homeschooling tunggal mempunyai sifat yang lebih progresif dan ulet dibandingkan dengan anak dengan homeschooling komunitas. Keadaan ini terlihat dengan penerapan homeschooling tunggal anak mampu menentukan pembelajaran yang disukainya dan ingin dipertahankan untuk menjadi lebih baik dan lebih ulet dibandingkan dengan homeschooling komunitas.

Dalam penelitian ini menunjukkan bahwa anak dengan homeschooling tunggal memiliki kemandirian seperti kebebasan yang ditunjukkan dengan tindakan yang dilakukan atas kehendak sendiri bukan karena paksaan orang lain dan tidak tergantung kepada orang lain. Pilihan untuk mengikuti jenis homeschooling tunggal merupakan pilihan sendiri dikarenakan adanya usaha untuk mengejar prestasi, penuh ketekunan, merencanakan, dan mewujudkan harapannya.

Hasil penelitian lebih lanjut menunjukkan bahwa tingkat kemandirian sebagian besar anak dengan homeschooling komunitas adalah sedang. Hal ini sesuai dengan pendapat Kembara (2007) yang mengatakan bahwa homeschooling komunitas memiliki konsep yang lebih terstruktur dan lengkap untuk pendidikan akademik, pembangunan akhlak mulia, penyapaian hasil belajar dan ruang gerak sosialisasi peserta didik lebih luas. Konsep seperti itu akan memudahkan pembentukan kemantapan diri dalam anak sehingga muncul sikap mandiri. Kemantapan diri yang dimiliki anak dikarenakan anak dalam homeschooling memokuskan pada kehidupan dan kemampuan yang dimiliki anak, yang akan membentuk anak bias menerima dirinya dan percaya diri atas kemampuan, tidak terpaku pada nilai atau angka yang menyebabkan anak tidak percaya diri dan akhirnya mendorong timbulnya perilaku 
menyontek untuk mendapatkan nilai bagus (Sumardiono, 2007).

Hasil penelitian ini senada dengan hasil penelitian Adilistiono (2009) yang menyatakan bahwa salah satu kekuatan atau kelebihan dilaksanakannya homeschooling komunitas adalah lebih mampu mendirikan kemandirian dan kreativitas individual yang bukan pembelajaran secara klasikal.

\section{DAFTAR PUSTAKA}

Adilistiono. (2009). Sikap Orang Tua Terhadap Pendidikan Homescooling. Skripsi. Medan: Jurusan Psikologi Universitas Sumatera Utara.

Astuti, S. (2004). Membuat Prioritas Melatih Anak Mandiri. Yogyakarta: Kansius.

Direktorat Pendidikan Kesetaraan. (2006). Komunitas Homeschooling Sebagai Satuan Pendidikan Kesetaraan. Jakarta.

Depdikbud. (1990). Kamus Besar Bahasa Indonesia. Jakarta: Balai Pustaka.

Drost, J. (2002). Peran sekolah dalam membentuk kemandirian. Kompas Cyber Media. Diakses tanggal 13 November 20012.

Edwards, D. (2006). Ketika Anak Sulit Diatur. Bandung : Kaifa.

Havighurst, J. (1986). Human Development and Education. Surabaya: Sinar Wijaya.

Hurlock, B. (1990). Psikologi Perkembangan Suatu Pendekatan Sepanjang Rentang Kehidupan. Jakarta: Erlangga.

Kartono K. (1987). Psikologi Anak. Bandung: Alumni.

Kartono K. (1987). Psikologi Anak.Bandung: Alumni.

Kartono K. (1987). Psikologi Anak. Bandung: Alumni.
Masrun; Martono; Haryono, F. K; Hardito, P; Sofiati, M; Bawani, A; Aritonang, L; Soetjipto, H. P. (1986). Studi mengenai kemandirian pada penduduk di tiga suku bangsa (Jawa, Batak, Bugis). Laporan Penelitian. Yogyakarta : Fakultas Psikologi Universitas Gadjah Mada.

Mulyadi, Seto. (2007). Home Schooling Keluarga Kak Seto. Bandung: PT Mizan Pustaka.

Mu'tadin, Zainun. (2002). Kemandirian Sebagai Kebutuhan Pikologis Pada Remaja. @yahoo.Com.

Partini, (1987). Perkembangan Anak. Jakarta: Bumi Aksa

Sarwono, S. (2000). Psikologi Remaja. Jakarta: PT. Raja Grafindo Persada

Soekresno, (2004). Alternative Pemilihan Sekolah. Diakses tanggal 22 februari 2012 dari www.News@Indosiar.com

Sumardiono. (2007). Apa itu homeschooling. Retrieved from www.sumardiono.com. 